\title{
SCREENING FOR B-THALASSEMIA CARRIER AMONG STUDENTS IN ASECONDARY SCHOOL IN DIARB NEGM,SHARKIA
}

\author{
Dr.Mervat Abdallah Hesham Professor of pediatrics Faculty of Medicine-Zagazig University \\ Dr.Mohammed Refaat Besher Professor of pediatrics Faculty of Medicine-Zagazig University \\ Dr.Naglaa Ali Khalifa Professor of clinical pathology Faculty of Medicine Zagazig University
}

\begin{abstract}
Background:Beta-Thalassemia represents a major public health problem in Egypt. The carrier rate varies between $5.5 \%$ to $\geq 9 \%$; it is estimated that there are 1000/1.5 million per year live births born with $\beta$ thalassemia. In spite of optimal treatment being available, only a few patients can afford it. Unfortunately, most patients suffer from complications of blood transfusions, mainly transfusion transmitted viral infections and iron overload. Prevention by carrier detection and prenatal diagnosis is needed in populations with high incidence of the disease, such as Egypt.

Methods:This was a prospective cross-sectional study conducted on 614 secondary school students in Diarb Negm, Sharkia Governorate. All subjects were subjected to the following: Complete blood count,Serum ferritin level, Serum iron level, TIBC. Subjects with microcytic anemia were subjected to specific laboratory tests: HPLC (High Performance Liquid Chromatography) which include hemoglobin A2(HbA2).

Results:Complete blood count testing of the 614 subjects in this study revealed that $55.2 \%$ were normal and $44 \%$ were anemic, $5.6 \%$ had normocytic anemia and $39.2 \%$ had microcytic anemia.Subjects with microcytic anemia were further subdivided into two groups according to their $\mathrm{HbA} 2$ level into; $\beta$-Thalassemia carrier group with high level of $\mathrm{HbA} 2>3.5 \%$ and normal to high (serum iron, serum ferritin) and normal to low TIBC were $8.5 \%$ and Non-carrier group; All with normal levels of $\mathrm{HbA} 2<3.5 \%$, low serum iron, low serum ferritin, high TIBC, were $31.6 \%$ of subjects and diagnosed as iron deficiency anemia.Carriers rate was $8.5 \%$, $53.8 \%$ were males and $46.2 \%$ were females.There were increase in mean value of RBCS count, serum iron and serum ferritin in carriers as compared to non-carriers, and decrease in mean value of HB, HCT, MCV, $\mathrm{MCH}, \mathrm{MCHC}$ find TIBC level in carriers as compared to non-carriers. There was a significant positive correlation between $\mathrm{HbA} 2$ and $\mathrm{HCT}, \mathrm{RBCS}$ count and serum ferritin, while significant negative correlation between HbA2and MCV.

Conclusion: Carrier rate among 614 secondary school students in Diarb Negm,Sharkia Governorate was 8.5\%.Hemoglobin A2 is the gold standard for B-Thalassemia carrier screening.

Key words: Beta-thalassemia; Microcytic hypochromic anemia; Screening; B-Thalassemia Carrier.

Corresponding author: Name: Gamal El-din Mamdouh Salem, Tel: 01003391963 ,
\end{abstract}

Email: dr_gamal_elsemary@yahoo.com

\section{INTRODUCTION}

T halassemia is a group of genetic disorders characterized by quantitative defects in globin chain synthesis with subsequent absence of $\mathrm{Hb}$ production leading to variable degree of microcytic anemia[1].Beta-thalassemia is caused by any of more than 200 mutations that affect different levels of the beta-globin gene expression by a variety of mechanisms[2]. The Beta-thalassemias are inherited in an autosomal recessive manner. The parents of an affected child are obligate heterozygotes and carry a single copy of a disease causing beta globin gene mutation. At conception, each child of heterozygotes parents has $25 \%$ chance of being affected, $50 \%$ chance of being an asymptomatic carrier, and $25 \%$ chance of being unaffected and not
carrier[3].Beta-thalassemia is the most common genetically inherited hemoglobin disorder in Egypt with a carrier rate varying from 5.3 to $>9 \%$ as reported by a study[4].Beta-thalassemia major is a chronic disorder of blood, having an extensive impact on life and presenting with hemolytic anemia, growth retardation, hepato-splenomegaly and skeletal abnormalities. It often requires regular blood transfusions, iron chelation therapy and sometimes splenectomy for its management. Thus, the therapeutic regime is complex, lifelong and inconvenient, requiring repeated hospitalizations and blood transfusions, which often affects the child's physical and mental health negatively[5].Haemoglobinopathies are possibly unique among all genetic diseases in that identification of carriers is possible (and 
preferable) by haematological (biochemical) tests rather than DNA analysis. Any at-risk couples can then be offered reproductive choice and avoid the birth of an affected child by undergoing prenatal diagnosis, which involves mutation characterization in the parents and subsequent fetal DNA analysis. Thus genetic services for haemoglobinopathies require close collaboration between several specialties, most notably haematology and molecular genetics[6]."Screening" is distinct from "definitive" diagnosis in that the purpose of screening is to test for a defined set of conditions using simple biochemical tests. Screening programmers are designed using a protocol of first and second line methods in order to obtain a reliable diagnosis, which is essentially a presumptive diagnosis. If an unequivocal, definitive diagnosis is required, characterization methods based on either protein or DNA analysis must be utilized[7].The study of the genetic heterogenicity in every population has provided a new understanding of the diseases phenotype, guided the management of the diseases and allowed successful prevention of the disease through prenatal diagnosis programs[8]. With the increase of the number of Egyptian population, updating the data of thalassemia carrier status is mandatory for the success of any preventive program.

\section{subjects}

\section{SUBJECTS AND METHODS}

This study was cross sectional study which was done in Pediatric Hematology \& Clinical Pathology departments in Zagazig University Hospital of pediatrics and carried out on 614 secondary school students from Diarb Negm,Sharkia aged from 15-18 years during the period from sep.2016 to sep 2017 Inclusion criteria included: Informed written parental consent was obtained from every subject which participated in this research. The study was also approved from the ministry of Education in El-Sharkia Governorate. Secondary school students were randomly selected.The participants had no signs or symptoms suggesting haematological disease. Exclusion criteria included: Students with other hemolytic diseases andstudents which refuse to participate in the study.

Clinical evaluation and laboratory data

For each subject entered in the study, careful history taking regarding: personal history, history of present illness, past history of diseases, operations \& medications, personal and family history.

Clinical examination were done includes general examination as heart rate, blood pressure, respiratory rate or pallor.

Laboratory Tests:

A- Complete Blood Count:The key components of the CBC include: hemoglobin, RBC count, mean corpuscular volume (MCV), and red cell distribution width (RDW). The thalassemia is generally classified as hypochromic microcytic anemia; hence the MCV is a key diagnostic indicator. Virtually all automated hematology analyzers now provide a measurement of MCV that is both precise and accurate. In most population screening programs $\mathrm{Hb}$ of less than 11(according to the age of secondary school children), MCV of less than 80fl and or $\mathrm{MCH}$ of less than $27 \mathrm{pg}$ are generally used as cut off points for further screening.

B- HbA2 Estimation:Raised hemoglobin A2 level is the gold standard for diagnosis of thalassemia trait. Subjects found to be positive to preliminary screening tests by red cell indices are confirmed for carrier state by HbA2 measurement using the haemglobin analyzer ARKRAY ADAMS A1C HA-8180T (Japan) device.

$C$ - Serum iron level by automated analyzer; normal range $70-200 \mu \mathrm{g} / \mathrm{dl}$.

D- Total iron binding capacity (TIBC) by automated analyzer; normal range 250$435 \mu \mathrm{g} / \mathrm{dl}$.

E- Serum ferritin: using Tosoh AIA1800ST (Japan) immunoassay analyzer. Ferritin in circulation, as measured in serum levels is satisfactory index of body iron storage. 
Table (1): Demographic data of the studied group:

RESULTS

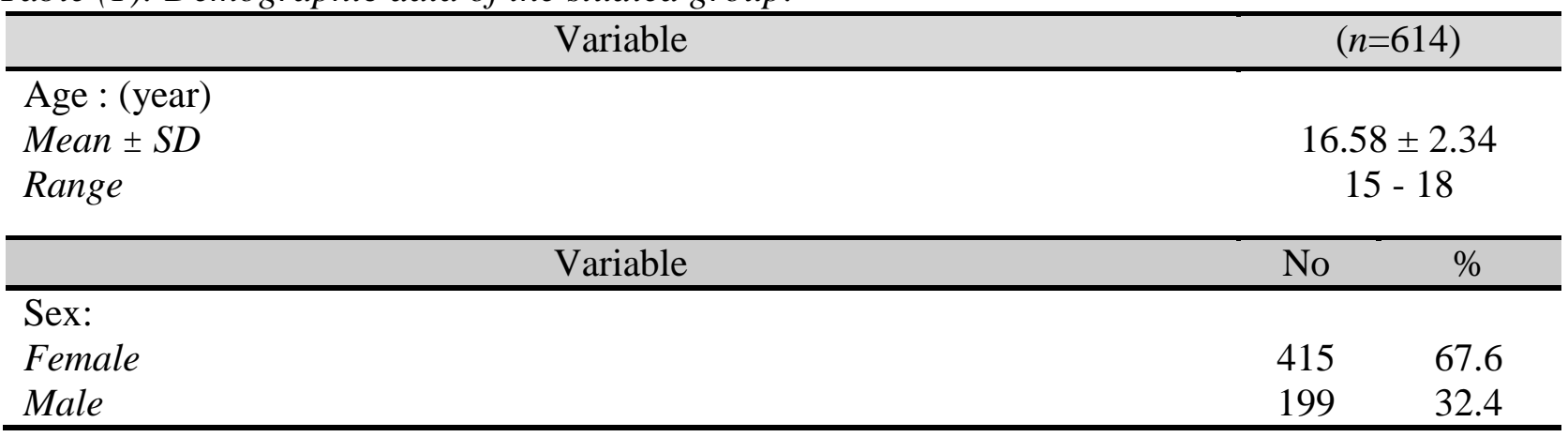

Sd: Stander deviation

This table shows that the age of the studied group ranged from 15 to 18 years with mean 16.58 years. Regarding sex $67.6 \%$ of them were female.

Table (2): CBC among the studied group:

\begin{tabular}{|c|c|c|}
\hline & Variable & $(n=614)$ \\
\hline Platelets: $\left(\mathrm{x} 10^{3} / \mathrm{mm}^{3}\right)$ & $\begin{array}{l}\text { Mean } \pm S D \\
\text { Median } \\
\text { Range }\end{array}$ & $\begin{array}{c}250.38 \pm 91.24 \\
241.5 \\
28-796\end{array}$ \\
\hline WBCs: $\left(\times 10^{3} / \mathrm{mm}^{3}\right)$ & $\begin{array}{l}\text { Mean } \pm S D \\
\text { Median } \\
\text { Range }\end{array}$ & $\begin{array}{c}8.48 \pm 4.28 \\
7.8 \\
2.2-55\end{array}$ \\
\hline RBCs: $\left(\times 10^{6} / \mathrm{mm}^{3}\right)$ & $\begin{array}{l}\text { Mean } \pm S D \\
\text { Range }\end{array}$ & $\begin{array}{l}4.30 \pm 0.53 \\
2.58-6.81 \\
\end{array}$ \\
\hline $\mathrm{Hb}:(\mathrm{gm} / \mathrm{dl})$ & $\begin{array}{l}\text { Mean } \pm S D \\
\text { Range }\end{array}$ & $\begin{array}{c}11.43 \pm 1.5 \\
6.4-17\end{array}$ \\
\hline HCT: & $\begin{array}{l}\text { Mean } \pm S D \\
\text { Range }\end{array}$ & $\begin{array}{c}36.45 \pm 4.29 \\
21.5-54 \\
\end{array}$ \\
\hline MCV: & $\begin{array}{l}\text { Mean } \pm S D \\
\text { Range }\end{array}$ & $\begin{array}{c}85.05 \pm 7.68 \\
62-107\end{array}$ \\
\hline MCH: & $\begin{array}{l}\text { Mean } \pm S D \\
\text { Range }\end{array}$ & $\begin{array}{l}26.71 \pm 2.8 \\
17.7-33.4\end{array}$ \\
\hline MCHC: & $\begin{array}{l}\text { Mean } \pm S D \\
\text { Range }\end{array}$ & $\begin{array}{c}31.25 \pm 1.75 \\
10.3-39\end{array}$ \\
\hline MPV: & $\begin{array}{l}\text { Mean } \pm S D \\
\text { Range }\end{array}$ & $\begin{array}{c}9.88 \pm 0.97 \\
7.8-13.6\end{array}$ \\
\hline RDWcy: & $\begin{array}{l}\text { Mean } \pm S D \\
\text { Range }\end{array}$ & $\begin{array}{l}11.92 \pm 1.6 \\
8.4-21.7\end{array}$ \\
\hline RDWsd: & $\begin{array}{l}\text { Mean } \pm S D \\
\text { Range }\end{array}$ & $\begin{array}{c}36.06 \pm 3.03 \\
27-50\end{array}$ \\
\hline
\end{tabular}

Sd: Stander deviation

This table shows that the Platelets number among the studied group ranged from 28 to 796 with mean $250.83 \times 10^{3} / \mathrm{mm}^{3}$ and WBCs count ranged from 2.2 to 55 with mean $8.84 \times 10^{3} / \mathrm{mm}^{3}$ and RBCs number ranged from 2.58 to 6.81 with mean $4.30 \times 10^{6} / \mathrm{mm}^{3}$.
Regarding $\mathrm{Hb}$ it ranged from 6.4 to 17 with mean $11.34 \mathrm{gm} / \mathrm{dl}$ and mean $\mathrm{HCT}, \mathrm{MCV}$, $\mathrm{MCH}, \mathrm{MCHC}$, MPV were $36.45,85.05$, $26.71,31.25$ and 9.88 respectively and finally RDW mean were 11.92 and 36.06 . 
Table (3): $M C V \&$ MCH results among the studied group:

\begin{tabular}{lcc} 
& Variable & \multicolumn{2}{c}{$(n=614)$} \\
\cline { 2 - 3 } & No & $\%$ \\
\hline MCV: & & 116 \\
$<80$ & 498 & 81.1 \\
$>80$ & 301 & 49 \\
\hline MCH: & 313 & 51 \\
$<27$ & & \\
$\geq 27$ & 304 & 49.5 \\
\hline Results: & & \\
$M C V<80$ \& or $M C H<27$ &
\end{tabular}

This table shows that $18.9 \%$ of the studied group had MCV less than 80 (microcytosis) also $49 \%$ had MCH less than 27 (hypochromia). Finally those had MCV $<80$ \& or $\mathrm{MCH}<27$ were $49.5 \%$.

Table (4): Confirmatory tests among microcytic hypochromic cases:

\begin{tabular}{llc}
\hline & \multicolumn{1}{c}{ Variable } & $(n=304)$ \\
\hline Ferritin: & Mean $\pm S D$ & $50.47 \pm 56.38$ \\
& Median & 23.6 \\
& Range & $5.6-200$ \\
\hline Serum Iron & Mean $\pm S D$ & $66.93 \pm 22.71$ \\
& Median & 57.2 \\
& Range & $36.7-103.9$ \\
\hline TIBC: & Mean $\pm S D$ & $329.85 \pm 57.67$ \\
& Range & $212-410$ \\
\hline HbA2: & Mean $\pm S D$ & $3.22 \pm 0.74$ \\
& Range & $0.10-6.5$ \\
\hline HbF: & Mean $\pm S D$ & $0.21 \pm 0.49$ \\
& Median & 0 \\
& Range & $0-3.5$ \\
\hline
\end{tabular}

Sd: Stander deviation

This table shows that the Ferritin among the studied group ranged from 5.6 to 200 with mean 50.47, Serum iron ranged from 36.7 to 103.9 with mean 66.93 and TIBC ranged from 212 to 410 with mean 329.85 . Also $\mathrm{HbF}$ ranged from 0 to 3.5 with mean 0.21 . Finally $\mathrm{HbA} 2$ ranged from 0.1 to 6.5 with mean 3.22 .

Table (5): Frequency of thalassemia carrier among the studied group:

\begin{tabular}{lcc}
\hline \multicolumn{1}{c}{ Variable } & \multicolumn{1}{c}{$(n=614)$} \\
\cline { 2 - 3 } & No & $\%$ \\
\hline Diagnosis: & 559 & 91.5 \\
No carrier & 52 & 8.5 \\
Thalassemia Carrier $(H b A 2>3.5)$ & & \\
\hline This table shows that $8.5 \%$ of the studied group were thalassemia carrier and $91.5 \%$ were not \\
carrier.
\end{tabular}


Table (6): Relation between Demographic data of the studied group and thalassemia:

\begin{tabular}{|c|c|c|c|c|c|c|}
\hline Variable & \multicolumn{2}{|c|}{$\begin{array}{c}\text { Non carrier } \\
(n=562)\end{array}$} & \multicolumn{2}{|c|}{$\begin{array}{l}\text { Carrier } \\
(\mathrm{n}=52)\end{array}$} & $\mathrm{t}$ & $\mathrm{P}$ \\
\hline \multicolumn{7}{|l|}{ Age : (year) } \\
\hline Mean $\pm S D$ & \multirow{2}{*}{\multicolumn{2}{|c|}{$\begin{array}{c}16.05 \pm 1.45 \\
15-18\end{array}$}} & \multirow{2}{*}{\multicolumn{2}{|c|}{$\begin{array}{c}15.89 \pm 2.10 \\
15-18\end{array}$}} & \multirow{2}{*}{0.75} & 0.46 \\
\hline Range & & & & & & NS \\
\hline Variable & $\mathrm{No}$ & $\%$ & $\overline{\mathrm{No}}$ & $\%$ & $\bar{\chi}^{2}$ & $\mathrm{P}$ \\
\hline \multicolumn{7}{|l|}{ Sex: } \\
\hline Male & 171 & 30.4 & 28 & 53.8 & \multirow[t]{2}{*}{11.92} & 0.001 \\
\hline Female & 391 & 69.6 & 24 & 46.2 & & $* *$ \\
\hline
\end{tabular}

Sd: Stander deviation $\mathrm{t}$ : Independent $\mathrm{t}$ test $\chi^{2}:$ Chi square test

NS: Non significant $(\mathrm{P}>0.05) \quad * *$ : Highly significant $(\mathrm{P}<0.01)$

This table shows that there were no statistical significance differences between carrier and non carrier in age but there were statistical significance increase in frequency of male among carriers.

Table (7): Relation between CBC of the studied group and thalassemia:

\begin{tabular}{|c|c|c|c|c|c|}
\hline & & $\begin{array}{c}\text { Non carrier } \\
(n=562)\end{array}$ & $\begin{array}{l}\text { Carrier } \\
(\mathrm{n}=52)\end{array}$ & $\mathrm{t} / \mathrm{MW}$ & $\mathrm{P}$ \\
\hline $\begin{array}{l}\text { Platelets: } \\
\left(\mathrm{x} 10^{3} / \mathrm{mm}^{3}\right)\end{array}$ & $\begin{array}{l}\text { Mean } \pm S D \\
\text { Range }\end{array}$ & $\begin{array}{c}245.11 \pm 88.72 \\
28-796\end{array}$ & $\begin{array}{c}307.35 \pm 99.33 \\
111-559\end{array}$ & 4.71 & $\begin{array}{c}<0.001 * \\
*\end{array}$ \\
\hline $\begin{array}{l}\text { WBCs: } \\
\left(\times 10^{3} / \mathrm{mm}^{3}\right)\end{array}$ & $\begin{array}{l}\text { Mean } \pm S D \\
\text { Range }\end{array}$ & $\begin{array}{c}8.41 \pm 4.41 \\
2.2-55 \\
\end{array}$ & $\begin{array}{c}9.28 \pm 2.44 \\
4.7-14.6 \\
\end{array}$ & 3.27 & $\begin{array}{c}0.001 \\
* * \\
\end{array}$ \\
\hline $\begin{array}{l}\text { RBCs: } \\
\left(\mathrm{x} 10^{6} / \mathrm{mm}^{3}\right)\end{array}$ & $\begin{array}{l}\text { Mean } \pm S D \\
\text { Range }\end{array}$ & $\begin{array}{l}4.27 \pm 0.53 \\
2.58-6.81 \\
\end{array}$ & $\begin{array}{c}4.5 \pm 0.51 \\
3.31-5.68 \\
\end{array}$ & 2.89 & $\begin{array}{c}0.004 \\
* * \\
\end{array}$ \\
\hline $\mathrm{Hb}:(\mathrm{gm} / \mathrm{dl})$ & $\begin{array}{l}\text { Mean } \pm S D \\
\text { Range }\end{array}$ & $\begin{array}{c}11.5 \pm 1.52 \\
7.4-17 \\
\end{array}$ & $\begin{array}{c}10.64 \pm 1.04 \\
6.4-11.9 \\
\end{array}$ & 4.03 & $\begin{array}{c}<0.001 * \\
*\end{array}$ \\
\hline HCT: & $\begin{array}{l}\text { Mean } \pm S D \\
\text { Range }\end{array}$ & $\begin{array}{c}36.62 \pm 4.37 \\
24.6-54\end{array}$ & $\begin{array}{c}34.68 \pm 2.78 \\
21.5-41.2\end{array}$ & 3.14 & $\begin{array}{l}0.002 \\
* *\end{array}$ \\
\hline MCV: & $\begin{array}{l}\text { Mean } \pm S D \\
\text { Range }\end{array}$ & $\begin{array}{c}85.73 \pm 7.29 \\
63-107 \\
\end{array}$ & $\begin{array}{c}77.65 \pm 7.97 \\
62-79 \\
\end{array}$ & 7.85 & $\begin{array}{c}<0.001 * \\
*\end{array}$ \\
\hline $\mathrm{MCH}:$ & $\begin{array}{l}\text { Mean } \pm S D \\
\text { Range }\end{array}$ & $\begin{array}{c}26.97 \pm 2.64 \\
18.1-33.4 \\
\end{array}$ & $\begin{array}{c}23.88 \pm 3 \\
17.7-26.8 \\
\end{array}$ & 7.97 & $\begin{array}{c}<0.001 * \\
*\end{array}$ \\
\hline MCHC: & $\begin{array}{l}\text { Mean } \pm S D \\
\text { Range }\end{array}$ & $\begin{array}{c}31.41 \pm 0.92 \\
27.3-39\end{array}$ & $\begin{array}{c}29.48 \pm 4.89 \\
10.3-32.1\end{array}$ & 7.99 & $\begin{array}{c}<0.001 * \\
*\end{array}$ \\
\hline MPV: & $\begin{array}{l}\text { Mean } \pm S D \\
\text { Range }\end{array}$ & $\begin{array}{l}9.9 \pm 0.93 \\
8.2-13.6 \\
\end{array}$ & $\begin{array}{c}9.77 \pm 1.21 \\
7.8-12.8 \\
\end{array}$ & 0.86 & $\begin{array}{c}0.39 \\
\text { NS }\end{array}$ \\
\hline RDW cy: & $\begin{array}{l}\text { Mean } \pm S D \\
\text { Range }\end{array}$ & $\begin{array}{c}11.84 \pm 1.54 \\
8.4-17.3 \\
\end{array}$ & $\begin{array}{c}12.76 \pm 2.01 \\
9.5-21.7 \\
\end{array}$ & 3.97 & $\begin{array}{c}<0.001 \\
* * \\
\end{array}$ \\
\hline RDW sd: & $\begin{array}{l}\text { Mean } \pm S D \\
\text { Range }\end{array}$ & $\begin{array}{c}36.14 \pm 3.06 \\
27-50\end{array}$ & $\begin{array}{c}35.21 \pm 2.46 \\
28-42\end{array}$ & 2.04 & $\begin{array}{l}0.06 \\
\mathrm{NS}\end{array}$ \\
\hline
\end{tabular}

Sd: Stander deviation $\quad \mathrm{t}$ : Independent $\mathrm{t}$ test $\quad \mathrm{MW}$ : Mann Whitney test

NS: Non significant $(\mathrm{P}>0.05) \quad * *$ : Highly significant $(\mathrm{P}<0.01)$

This table shows that there were no statistical significance differences between carriers and non carriers in MPV or RDW sd count but there were statistical significance differences between them in all other $\mathrm{CBC}$ finding 
Table (8): Relation between confirmatory tests of the studied group and thalassemia:

\begin{tabular}{|l|l|c|c|c|c|}
\hline \multicolumn{2}{|c|}{ Variable } & $\begin{array}{c}\text { Non carrier } \\
(n=252)\end{array}$ & $\begin{array}{c}\text { Carrier } \\
(\mathrm{n}=52)\end{array}$ & t/MW & $\mathrm{P}$ \\
\hline Ferritin: & Mean $\pm S D$ & $43.33 \pm 45.55$ & $67.14 \pm 76.73$ & 2.53 & 0.02 \\
& Range & $5.6-150.4$ & $10.4-200$ & & $*$ \\
\hline Serum Iron & Mean $\pm S D$ & $60.8 \pm 22.39$ & $81.22 \pm 16.94$ & 2.65 & 0.01 \\
& Range & $37.6-103.9$ & $57-195.8$ & & $*$ \\
\hline TIBC: & Mean $\pm S D$ & $339.5 \pm 52.79$ & $307.32 \pm 65.39$ & 1.43 & 0.17 \\
& Range & $237.2-410.7$ & $212-386.2$ & & NS \\
\hline HbA2: & Mean $\pm S D$ & $3.01 \pm 0.48$ & $4.05 \pm 0.97$ & 10.91 & $<0.001 *$ \\
& Range & $0.1-3.5$ & $3.6-6.5$ & & $*$ \\
\hline HbF: & Mean $\pm S D$ & $0.20 \pm 0.40$ & $0.28 \pm 0.76$ & 3.12 & 0.003 \\
& Range & $0-1.8$ & $0.1-3.5$ & & $* *$ \\
\hline
\end{tabular}

Sd: Stander deviation t: Independent t test MW: Mann Whitney test

NS: Non significant $(\mathrm{P}>0.05) \quad * *$ : Highly significant $(\mathrm{P}<0.01)$

This table shows that there were no statistical significance differences between carriers and non carriers in TIBC but there were statistical significance differences between them in ferritin, serum iron, $\mathrm{HBA} 2$ and $\mathrm{HbF}$.

\section{DISCUSSION}

The thalassemias are inherited disorders of Hemoglobin $(\mathrm{Hb})$ synthesis resulting from an alteration in the rate of globin chain production[9].In Egypt, the oldest civilization in the Mediterranean region, thalassemia is the most frequent hemoglobin disorder in the country. The carrier rate of this disease varies between 5.3 and $\geq 9 \%$. It was estimated that $1,000 / 1.5$ million per year live birth born with thalassemia disease[10].Beta thalassemia major is a serious life-limiting and potentially life-threatening condition that causes substantial disruption in education and social activities. Children often need to miss school because of hospital appointments or admissions for regular monthly blood transfusion and/or treatment of complications. Their self-identity is compromised and they become increasingly dependent upon others[11].Thalassemia is recognized as the most prevalent hereditary disorder all over the world with a significant negative impact on public health and the society especially endemic areas[12]. The most prevalent hemoglobinopathy in Egypt is $\beta$-thalassemia major $(\beta-\mathrm{TM})$ which is a hereditary genetic anemia of hemolytic type. It is considered in our region a problematic health issue[13].The life expectancy of patients with $\beta$-thalassemia has greatly improved over the last few years as a result of regular blood transfusions and increased compliance with iron chelation therapy[14].Several countries have set up comprehensive national prevention programs, which include public awareness and education, carrier screening and counseling as well as information on prenatal diagnosis and pre implantation diagnosis. These countries are Italy, Greece, Cyprus, UK, France, Iran, Thailand, Australia, Singapore, Taiwan, Hong Kong and Cuba[15].Community screening is an important component of identifying carriers in the country. Whether carrier screening should be done at school or college level, before or after marriage or during pregnancy is debatable[16].

The aim of the present work was to identify carriers among secondary school children in Diarb Negm,EL-Sharkia Governorate to be taken in consideration of prevention program of $\beta$-thalassemia and to update carrier rate data at EL-Sharkia Governorate.This study was carried on 614 secondary school students in Diarb Negm, ElSharkia Governorate.Analysis of the results of studied subjects revealed the following: As regards to demographic data of the current study, our results showed that the age of all studied subjects ranged from 15 to 18 years with a mean value of $16.58 \pm 2.34$. This result was in agreement with the data published by 
El-Beshlawy et al, (2007) who reported on study of 1000 randomized school-aged children (5-16 years), their mean age is $10 \pm 3$ yearS[7].As regard to sex distribution in the present study: males were 199 subjects $(32.4 \%)$ and females were 415 subjects $(67.6 \%)$.Subjects with anemia were further subdivided into 28 subjects (5.6\%) had normocytic anemia and 196 subjects $(39.2 \%)$ had microcytic anemia. Subjects with microcytosis were further subdivided into two groups according to their $\mathrm{HbA} 2$ level; $\beta$ Thalassemia carrier group with high level of $\mathrm{HbA} 2 \geq 3.5 \%$ and normal iron profile parameters (serum iron, serum ferritin and TIBC) were 38 subjects $(8.5 \%)$ and noncarrier group; All with normal levels of $\mathrm{HbA} 2$ $<3.5 \%$, low serum iron, high TIBC and low serum ferritin were 158 subjects $(31.6 \%)$ and diagnosed as iron deficiency anemia. This results were in agreement with the data published by El-Beshlawy et al., (2007) whom study reported that 412 subjects $(41.2 \%)$ from screened subjects show microcytosis, their participants are divided into groups according to their $\mathrm{HbA} 2$ level, $\mathrm{HbF}$ level and iron status. The $\beta$-thalassemia carriers group are 90 children $(9 \%)$ with high levels of $\mathrm{HbA} 2>3.6 \%$ and normal levels of the iron parameters. The iron deficiency group is $(31.0 \%)$ with normal levels of $\mathrm{HbA} 2$ (range $1.3 \%-2.4 \%$ ), low serum iron and normal to high TIBC[7].In this study the prevalence of iron deficiency anemia among the screened subjects was $158(31.6 \%)$, iron deficiency remains the most common cause of microcytic anemia worldwide due to bad nutritional status, parasitic infestation, improper weaning, and early introduction of cow milk. The results were in agreement with agreement with EI-Beshlawy et al., (2007) who reported in their study the prevalence of iron deficiency anemia is $31 \%$ (301 subjects). The results were not in agreement with Kilbride et al., (2000) who reported that the prevalence of IDA is $43 \%$ and $55 \%$ among studied sample of school children in Cairo and El-Minofia, respectively[17].The results were also not in agreement with Elalfy et al., (2012) who reported that the frequency of anemia In Egypt (as developing countries) is much higher than developed countries, the frequency of IDA was $64 \%$ among the studied group in Al-Fayom Governorate[18].Kim et al., (1996) reported that high prevalence of iron deficiency among Al-Fayom population may be explained by the consumption of unfortified cow's milk feeding during the $1^{\text {st }}$ year of life, low intake of iron-rich foods, increased needs for iron duo to rapid growth, intestinal parasitic infestation or frequent consumption of tea with meals. Unfortified cow's milk is not only a poor sourco of iron, but its use may also be associated with occult blooding from the gut[19].And, also, not in agreement with Karkar et al., (2004) and Hay et al., (2004) they reported that the prevalence of IDA is $72 \%$ and $69 \%$ among children in Jordan and India, respectively[20].Zawilla, (2013) reported that strategies to control IDA in Egypt include daily and intermittent iron supplementation, home fortification with micronutrient powders, fortification of staple foods and condiments are activities to improve dietary diversity. The safety of routine iron supplementation in settings where infectious diseases, particularly malaria, are endemic, remains uncertain. The WHO is revising global guidelines for controlling IDA[21]. As regard to results of laboratory data of the present study, our results showed that; there were increase in mean value of RBCS count, serum iron and serum ferritin in carriers as compared to non-carriers, and decrease in mean value of $\mathrm{HB}, \mathrm{HCT}, \mathrm{MCV}$, $\mathrm{MCH}, \mathrm{MCHC}$ find TIBC level in carriers as compared to non-carriers.In the presented study, in carrier groups: There was a significant positive correlation between $\mathrm{HbA} 2$ and HCT, RBCS count and serum ferritin, while significant negative correlation between $\mathrm{HbA} 2$ and MCV.These results were in some agreement with ACOG Practice Bulletin (2007); (American college of ObstericiansGyancologist) who reported significant negative correlation between both $\mathrm{Hb}$ level, MCV with $\mathrm{HbA} 2$ but in our study there is no significant correlation between $\mathrm{Hb}$ level and HbA2.[22] Our study is not in agreement with Winichagoon et al., (1999) who reported that microcytosis and hypochromia in thalassemia trait may be greater than expected for the mild degree of anemia, but in iron deficiency cases, 
microcytosis was related to the degree of anemia[23].

\section{CONCLUSION}

Carrier rate among 614 secondary school students in Diarb Negm,Sharkia Governorate was $8.5 \%$.Hemoglobin A2 is the gold standard for B-Thalassemia carrier screening.

\section{REFRENCES}

1. Settin AA, Al-Haggar MM, Neamatallah M, AlSaid AM and Hafez MM. Detection of betathalassaemia mutations using primer-specific amplification compared to reversed dot blot hybridization technique in Egyptian cases. Haema, 2006; 9(3): p. 401-409.

2. Higgs DR, Engel JD and Stamatoyannopoulos G. Thalassaemia. The Lancet, 2012.; 379(9813):373383.

3. Galanello $\mathbf{R}$ and Origa $\mathbf{R}$. Beta-thalassemia. Orphanet J Rare Dis, 2010;5: p.11.

4. National Heart $L$ and Blood Institute (NHLBI). What Are Thalassemias? Health Topics 2013 [cited $2014 \quad 7$ Dec]; Blood Diseases and Disorders].Available from: http://www.nhlbi.nih.gov / health / healthtopics / topics / thalassea.

5. El-Beshlawy A, Kaddah N, Moustafa A, Mouktar G and Youssry I. Screening for betathalassaemia carriers in Egypt: significance of the osmotic fragility test. Eastern Mediterranean health journal, 2007;13(4): 780-786.

6. Hongally C, Benakappa AD and Reena S. Study of behavioral problems in multi-transfused thalassemic children. Indian journal of psychiatry, 2012; 54(4): p.333.

7. Old J, Traeger-Synodinos J, Galanello R, Petrou $M$ and Angastiniotis $M$. Prevention of thalassaemias and other haemoglobin disorders, in Thalassaemia International Federation Publications. 2005;2:113-116.

8. Christopoulos G, Ezzat $G$ and Kleanthous $M$. Use of denaturing gradient gel electrophoresis in screening unknown $\beta$-thalassemia mutations in Egyptian patients. Egyptian Journal of Medical Human Genetics, 2012.;13(3): p.343-349.

9. Weatherall DJ. Hemoglobinopathies worldwide: Present and future. Curr Mol Med. 2008;8(7):592599.

10. El-Beshlawy A and Youssry I. Prevention of Hemoglobinopathies in Egypt. Hemoglobin 2009; 33(1): 14-20.
11. Atkin $K$ and Ahmad W. Living a young people coping with thalassemia major or sickel cell disorder. Soc Sci Med, 2001; 53:615-626.

12. Gumuş $P$, Kahraman-Çeneli $S$, Akcali A, Sorsa T, Tervahartiala $\mathbf{T}$, Buduneli $\mathbf{N}$ and Ozçaka $O$. Association of thalassemia major and gingival inflammation. Arch Oral Biol, 2016; 64: 80-84.

13. Zahran AM, Elsayh KI, Saad K, Embaby M and Ali AM. Regulatory B cells (CD19 (+)CD38(hi)CD24(hi)) in alloimmunized and nonalloimmunized children with beta-thalassemia major. Blood Cells Mol Dis, 2016; 57: 91-96.

14. Pirinccioglu AG, Akpolat V, Koksal O, Haspolat $\mathbf{K}$ and Soker M. Bone mineral density in children with beta-thalassemia major in Diyarbakir. Bone. 2011; 49: 819-823.

15. Kalokairinou EM. The experience of $\beta$ thalassemia and its prevention in Cyprus. Med law 2007; 26(2): 291-307

16. Sangkitporn S, Sangkitporn S, Sangnoi A, Supangwiput $O$ and Tanphaichitr VS. "Validation of osmotic fragility test and dichlorophenol indophenol precipitation test for screening of thalassemia and $\mathrm{Hb}$ E." Southeast Asian journal of tropical medicine and public health, 2005; 36(6):1538

17. Kilbride J, Baker TG, Parapia LA and Khoury SA. Incidence of Iron-deficiency anemia in infants in a prospective study In Jordan. Eur $\mathbf{J}$ Hematol 2000; 64(4):231-6.

18. Elalfy MS, Hamdy AM, Maksoud SS and Megeed RI. Patterns of milk feeding and family size as risk factors for Iron deficiency anemia among poor Egyptian infants 6 to 24 months old, Nutr Res, 2012; 32(2):93-9.

19. Kim SK, Cheong WS, Jun YH, Choi JW and Son BK. Red blood cell Indices and iron status according to feeding practices in infants and young children. Acta Pediatr, 1996; 85(2):139-44.

20. Karkar PD and Kotecha PV. Prevalence of anemia among students of Nursing School of Vadodara. Nurs J India, 2004; 95:257-8.

21. Zawilla N. Iron deficiency anemia in Egypt. The Health, 2013; 4(3):58.

22. ACOG: ACOG Practice Bulletin - Clinical Management Guidelines for ObstetriciansGynecologists- Hemoglobinopathies in Pregnancy. Obstet. Gynecol, 2007; 109:229-237.

23. Winichagoon $P$, Saechan $V$, Sripanich $R$, Nopparatana C, Kanokpongsakdi S, Maggio A and Fucharoen $S$. prenatal diagnosis of $\beta$ thalassaemia by reverse dot-blot hybridization. $\mathrm{Br} \mathbf{~ J}$ Haematol 1999; 19(5):428-35. 